\title{
ANALISIS PELAKSANAAN PEMENUHAN HAK ATAS INFORMASI DAN HAK KESEHATAN REPRODUKSI PEREMPUAN PENYANDANG DISABILITAS DI KOTA SEMARANG
}

\author{
Maria Petronela W.M' ${ }^{\mathbf{1}}$, Agnes Widanti S ${ }^{\mathbf{1}}$, Edward Kurnia Setiawan Limijadi ${ }^{1,2}$ \\ ${ }^{1}$ Fakultas Hukum dan Komunikasi Universitas Katolik Soegijapranata, Semarang \\ ${ }^{2}$ Departemen Forensik dan Medikolegal Fakultas Kedokteran Universitas Diponegoro, Semarang \\ edwardksl@fk.undip.ac.id
}

\begin{abstract}
Abstrak
Penelitian ini bertujuan untuk menganalisis bagaimana pemenuhan hak atas informasi dan hak kesehatan reproduksi perempuan penyandang disabilitas di Kota Semarang. Terbatasnya akses informasi dan sempitnya ruang gerak bagi pendidikan kesehatan reproduksi serta kurangnya fasilitas kesehatan yang ramah bagi penyandang disabilitas di Indonesia berdampak terhadap terjadinya kekerasan seksual bagi perempuan penyandang disabilitas. Kota Semarang merupakan salah satu kota dengan jumlah kasus ketidakadilan penyandang disabilitas yang tinggi. Penelitian ini merupakan penelitian yuridis sosiologis dengan spesifikasi penelitian deskriptif analitis dengan data yang digunakan adalah data primer dan sekunder yang dianalisis secara kualitatif. Hasil penelitian ini menunjukkan bahwa hak atas informasi bagi perempuan penyandang disabilitas di Kota Semarang sudah terpenuhi namun, hak kesehatan reproduksi bagi perempuan penyandang disabilitas di Kota Semarang belum terpenuhi karena kurangnya anggaran dana dari pemerintah, tidak adanya sosialisasi seputar kesehatan reproduksi dari lembaga terkait, kurangnya kompetensi tenaga kesehatan untuk berkomunikasi dengan penyandang disabilitas, kurang berpartisipasinya masyarakat dalam mendukung penyandang di disabilitas, tidak adanya informasi kesehatan reproduksi yang diberikan kepada para penyandang disabilitas, serta tidak terlaksananya kebijakan yang telah dibuat.
\end{abstract}

Kata kunci : Disabilitas; Hak Informasi; Kesehatan Reproduksi

\section{ANALYSIS OF THE IMPLEMENTATION OF INFORMATION RIGHTS AND REPRODUCTIVE HEALTH RIGHTS OF WOMEN WITH DISABILITIES IN THE CITY OF SEMARANG}

\begin{abstract}
This study aims to analyze how the fulfillment of the right to information and reproductive health rights of women with disabilities in Semarang, Indonesia. Limited access to information and limited space for reproductive health education and health facilities that are not friendly to persons with disabilities in Indonesia have an impact on the occurrence of sexual violence for women with disabilities. Semarang is one of the cities with a high number of cases of injustice for persons with disabilities. This research is a sociological juridical research with descriptive analytical research specifications with the data used are primary and secondary data which were analyzed qualitatively. The results of this study indicate that the right to information for women with disabilities in Semarang has been fulfilled, however, reproductive health rights for women with disabilities in Semarang have not been fulfilled due to lack of budget funds from the government, lack of socialization about reproductive health from related institutions, lack of competence health workers to communicate with people with disabilities, the lack of community participation in supporting people with disabilities, the absence of reproductive health information provided to people with disabilities, and the non-implementation of policies that have been made.
\end{abstract}

Keywords : Right to Information, Reproductive Health, Disabilities 
e-ISSN : 2621-4105

\section{A. PENDAHULUAN}

Kesehatan merupakan salah satu hak asasi setiap manusia seperti yang diamanatkan dalam Undang-Undang Dasar 1945. ${ }^{1}$ Undang-Undang Dasar 1945 Pasal 28 H menyatakan bahwa setiap orang berhak hidup sejahtera lahir dan batin, bertempat tinggal dan mendapatkan lingkungan hidup yang baik dan sehat serta berhak memperoleh pelayanan kesehatan. Pasal 34 ayat (3) juga menyatakan bahwa negara bertanggung jawab atas penyediaan fasilitas pelayanan umum termasuk fasilitas kesehatan yang layak bagi setiap warga negara Indonesia.

Undang-Undang Nomor 36 Tahun 2009 tentang Kesehatan dalam Pasal 4, 5, 6, 7, dan 8 telah menjelaskan secara rinci terkait hak masyarakat dalam bidang kesehatan. Undang-Undang tentang kesehatan menjabarkan bahwa lingkup kesehatan tidak hanya seputar pelayanan kesehatan namun, pemberian informasi pada masyarakat juga menjadi poin penting di bidang kesehatan. Sempitnya ruang gerak bagi pendidikan kesehatan reproduksi sehingga membawa dampak bagi pihak manapun yang seharusnya memiliki hak untuk mendapatkan akses berupa informasi dari kesehatan reproduksi ini yaitu salah satunya adalah para kaum atau penyandang disabilitas.

Definisi kesehatan reproduksi menurut Undang-Undang Nomor 36 Tahun 2009 adalah keadaan sehat secara fisik, mental, dan sosial secara utuh, tidak semata-mata bebas dari penyakit atau kecacatan yang berkaitan dengan sistem, fungsi, dan proses reproduksi pada laki-laki dan perempuan. Berdasarkan WHO (2009), terdapat beberapa masalah kesehatan reproduksi yang sering dialami oleh para penyandang disabilitas. Penyandang disabilitas dianggap tidak bisa bertanggung jawab atas tubuhnya sendiri, sering dipaksa melakukan hal yang tidak disadari, lebih berisiko menjadi korban pelecehan seksual, kesulitan mengakses layanan, dan dianggap tidak penting karena mereka dianggap tidak aktif secara seksual. Pawestri (2017) dalam artikelnya menuliskan bahwa usaha perlindungan terhadap penyandang disabilitas untuk dapat memenuhi haknya juga disesuaikan dengan perspektif hak asasi manusia (HAM) internasional dan nasional yang diturunkan dalam instrumen HAM internasional dan juga instrumen hukum nasional yang dijabarkan di dalam peraturan perundangan terkait. ${ }^{2}$

Penelitian sebelumnya oleh Rofiah (2016) menjelaskan bahwa hambatan yang dialami dalam upaya penegakan hukum bagi para penyandang disabilitas khususnya perempuan yang mengalami kasus kekerasan seksual yaitu adanya faktor internal dari individu penyandang disabilitas itu sendiri. ${ }^{3}$ Penyandang disabilitas tidak dapat melakukan perlawanan pada saat mengalami kekerasan seksual, tidak dapat memahami situasi, kondisi dan akibat dari kekerasaan seksual yang mereka alami, serta kurangnya pemahaman terkait hak yang meraka miliki baik itu dalam hal memperoleh informasi

1 Tim Penulis Sobat ASK, "5 Masalah Seksualitas Yang Dialami Penyandang Disabilitas," 2017, http://www.sobatask.net.

${ }^{2}$ Aprilia Pawestri, "Hak Penyandang Disabilitas Dalam Perspektif Ham Internasional Dan Ham Nasional,” Era Hukum 15, no. 1 (2017): 164-82.

3 S Rofiah, "Harmonisasi Hukum Sebagai Upaya Meningkatkan Perlindungan Hukum Bagi Perempuan Penyandang Disabilitas Korban Kekerasan Seksual," Qawwam 11, no. September 2016 (2017): 133-50, https://journal.uinmataram.ac.id/index.php/qawwam/article/view/747. 
kesehatan dan juga hal terkait perlindungan hukum. Upaya yang perlu dilakukan untuk menjamin perlindungan hukum bagi penyandang disabilitas adalah dilakukannya harmonisasi hukum yaitu penyesuaian kerangka sistem hukum nasional yang mencakup komponen materi hukum (legal substance),struktur hukum beserta kelembagaannya (legal structure) dan komponen budaya hukum (legal culture). Bentuk harmonisasi hukum yaitu penyusunan Peraturan Perundang-undangan (PP) sebagai pelaksanaan dari UU Nomor 8 Tahun 2016.

Dua tahun setelah penyusunan UU No.8 Tahun 2016 tentang Penyandang Disabilitas, Peraturan Perundangan (PP) yang dapat menjelaskan bagaimana implementasi dari Undang-Undang tersebut belum juga disahkan. Sedangkan penelitian oleh Irawan (2017) menjelaskan bahwa lambatnya pengesahan aturan tersebut menimbulkan kesulitan pemerintah dan pemerintah daerah untuk dapat memenuhi hakhak penyandang disabilitas. ${ }^{4}$ Penegakan hukum bagi penyandang disablitas sulit ditegakan akibat sikap dan cara pandang masyarakat serta penegak hukum yang masih menganggap penyandang disabilitas merupakan kelompok masyarakat yang lemah. Belum terakomodirnya kebutuhan penyandang disabilitas dan belum tersedianya fasilitas-fasilitas umum yang ramah bagi penderita disabilitas juga menjadi hambatan utama lemahnya penegakan hukum bagi penyandang disabilitas.

Pemerintah daerah memiliki peranan penting untuk mewujudkan penegakan hukum bagi penyandang disabilitas. Peran Pemerintah Daerah Istimewa Yogyakarta dalam upaya perlindungan hukum terhadap perempuan penyandang disabilitas korban kekerasan, adalah membuat aturan hukum yang berbentuk Peraturan Daerah dan peraturan pelaksanaannya baik dalam hal perlindungan dan pemenuhan hak-hak perempuan penyandang disabilitas korban kekerasan. ${ }^{5}$ Upaya lain adalah dengan menyediakan lembaga pemerintah yang bertugas dalam memantau dan mengawal implementasi Peraturan Daerah Daerah Istimewa Yogyakarta Nomor 4 Tahun 2012 tentang Perlindungan dan Pemenuhan Hak-hak Penyandang Disabilitas serta secara khusus memberikan layanan bagi penyandang disabilitas yang berhadapan dengan hukum termasuk terhadap perempuan penyandang disabilitas korban kekerasan.

Asosiasi Lembaga Bantuan Hukum Asosiasi Perempuan Indonesia Untuk Keadilan (LBH APIK) menyatakan bahwa dalam kurun waktu satu tahun, paling tidak terdapat 62 kasus ketidakadilan yang menimpa perempuan penyandang disabilitas. Data tersebut diperoleh melaui survei di tujuh kota Indonesia yaitu Semarang, Makassar, dan Palu. Dari 724 disabilitas yang di survei, 62 mengalami kasus ketidakadilan, dan yang terbanyak yaitu mengalami pelecehan seksual. ${ }^{6}$

${ }^{4}$ RR. Putri A. Priamsari, "Hukum Yang Berkeadilan Bagi Penyandang Disabilitas," Masalah-Masalah Hukum 48, no. 2 (2019): 215, https://doi.org/10.14710/mmh.48.2.2019.215-223.

5 Ardi Irawan, "Peranan Pemerintah Daerah Istimewa Yogyakarta Dalam Perlindungan Hukum Terhadap Perempuan Penyandang Disabilitas Korban Kekerasan,” Jurnal Ilmiah Hukum De’Jure Volume 2, no. Nomor 2 (2017): 2013-2218.

${ }^{6}$ Ignatius Herjantam, "Perempuan Penyandang Disabilitas Rentan Alami. Ketidakadilan Berlapis," 2017, http://www.beritasatu.com. 
Berdasarkan uraian diatas, penelitian sebelumnya hanya membahas faktor-faktor penyebab rendahnya upaya penegakan hukum pada penyandang disabilitas serta upaya apa yang perlu dan sudah dilakukan untuk meningkatkan penegakan hukum bagi penyandang disabilitas. Sedangkan penelitian ini bertujuan untuk menganalisis bagaimana implementasi atau pelaksanaan dari upaya pemerintah dalam hal pemenuhan hak kesehatan yaitu hak atas informasi dan hak kesehatan reproduksi para perempuan penyandang disabilitas.

\section{B. PERMASALAHAN}

Rumusan masalah dalam penelitian ini yaitu :

1. Bagaimana peraturan yang melindungi pemenuhan hak atas informasi dan hak kesehatan reproduksi bagi perempuan penyandang disabilitas?

2. Bagaimana pelaksanaan pemenuhan hak atas informasi dan hak kesehatan reproduksi bagi perempuan penyandang disabilitas?

3. Faktor-faktor apa saja yang menjadi penghambat dan pendukung pelaksanaan pemenuhan hak atas informasi dan hak kesehatan reproduksi bagi perempuan penyandang disabilitas?

\section{B. METODE PENELITIAN}

Penelitian ini menggunakan metodologi hukum Socio-Legal. Penelitian SocioLegal bertumpu pada data utama dari lapangan, yakni melalui informan yang diperoleh dengan cara wawancara secara mendalam, serta untuk mendukung data tersebut, digunakan data bahan hukum, yang diperoleh melalui kajian pustaka. ${ }^{7}$ Data hukum yang digunakan yaitu data primer dan data sekunder. Data primer diperoleh melalui wawancara mendalam (deep interview).

Data primer penelitian ini diperoleh dari hasil wawancara mendalam terhadap responden dari KSD (Komunitas Sahabat Disfabel) yang berjumlah 6 orang yaitu 5 orang penyandang disabilitas dari golongan tuna grahita dan 1 dari tuna netra. Ke enam orang tersebut kemudian digolongkan ke dalam dua tingkatan ekonomi yaitu 3 orang menengah ke atas dan 3 orang menengah ke bawah. Narasumber dalam penelitian ini terdiri dari ketua komunitas KSD, Ketua Dinas Kesehatan Kota Semarang, Dinas Sosial Kota Semarang, DP3A Kota Semarang, PKBI (Perkumpulan Keluarga Berencana Indonesia) Kota Semarang, dan SLB Hj.Soemiyati. Data sekunder dalam penelitian ini berupa bahan hukum dan data sekunder lain yang menunjang penelitian ini melalui studi pustaka. ${ }^{8}$

Responden dalam penelitian ini diambil dengan cara purposife sampling. Responden yang diambil yaitu para perempuan penyandang disabilitas di Kota Semarang digolongkan berdasarkan kelompok ekonomi yaitu kelompok ekonomi menengah ke bawah dan ekonomi menengah ke atas. Pengumpulan data dilakukan pada unit sampling tersebut, respenden dalam penelitian ini tidak termasuk para penyandang disabilitas di kota lain, maupun para penyandang disabilitas yang bukan berjenis kelamin perempuan.

7 Kornelius Benuf and Muhamad Azhar, "Metodologi Penelitian Hukum Sebagai Instrumen Mengurai Permasalahan Hukum Kontemporer," Metodologi Penelitian Hukum Sebagai Instrumen Mengurai Permasalahan Hukum Kontemporer 3, no. 2 (2019): 145-60.

${ }^{8}$ H.Zinuddin Ali, Metode Penelitian Hukum (Sinar Grafika, 2015). 
Hasil penelitian akan dipaparkan dalam bentuk deskriptif dan dianalisis dengan peraturan perundang-undangan yang terkait.

\section{HASIL DAN PEMBAHASAN}

\section{Peraturan Tentang Pemenuhan Hak atas Informasi dan Hak Kesehatan Reproduksi Bagi Perempuan Penyandang Disabilitas}

Pemenuhan hak penyandang disabilitas telah sepenuhnya tertuang dalam UndangUndang No.8 Tahun 2016. Hak atas informasi dan hak kesehatan merupakan Sebagian dari hak yang dimiliki oleh penyandang disabilitas yang juga diatur dalam UndangUndang No.8 Tahun 2016. Pada kenyataannya, terdapat beberapa hambatan yang dialami dalam upaya implementasi dari UU No.8 Tahun 2016. Terdapat tiga faktor utama yang menjadi hambatan dalam pelaksanaan upaya pemenuhan hak penyandang disabilitas khususnya di Kota Semarang, Jawa Tengah yaitu faktor substansi hukum, struktur pemerintahan, dan budaya masyarakat.

Substansi hukum meliputi belum adanya ketentuan-ketentuan yang mengatur mengenai perlindungan dan pemenuhan hak penyandang disabilitas khususnya di tingkat daerah masih sangat minim dalam hal ini masih mengacu pada Undang-Undang No 8 Tahun 2016 tentang Penyandang Disabilitas. Faktor kedua adalah budaya masyarakat dimana sebagian besar masyarakat masih memiliki sikap diskriminatif terhadap para penyandang disabilitas serta kurangnya kesadaran untuk mematuhi hukum yang berlaku. Faktor yang terakhir adalah struktur pemerintah dimana sebagian besar aparat pemerintah khususnya di Kota Semarang memiliki pemahaman yang rendah terkait hak yang dimiliki oleh penyandang disabilitas serta bagaimana cara memperlakukan atau memberikan pelayanan yang ramah penyandang disabilitas.

\section{a) Hak Atas Informasi}

Hak memperoleh informasi merupakan sebuah kebutuhan yang paling mendasar bagi setiap manusia. Informasi merupakan salah satu kebutuhan pokok untuk mengembangkan pribadi setiap manusia dan lingkungannya baik secara politik, ekonomi, sosial budaya dan keamanan. Negara memiliki kewajiban untuk membuka akses seluasluasnya bagi setiap warga negara tanpa terkecuali untuk mendapatkan informasi. Setiap orang memiliki hak untuk memperoleh informasi yang telah diatur dalam UUD 1945 Pasal 28 F. Peraturan ini juga sesuai dengan apa yang dituliskan oleh Ridlwan (2013) bahwa perlindungan hak-hak penyandang disabilitas merupakan hak konstitusional yang terdapat dalam UUD $1945 .{ }^{9}$

Hak untuk memperoleh informasi diatur dalam Undang-Undang Nomor 14 Tahun 2008 Pasal 2 Ayat (1) tentang Keterbukaan Informasi Publik, sedangkan bagi penyandang disabilitas, hak untuk memperoleh informasi diatur dalam Undang-Undang Nomor 8 Tahun 2016 tentang Penyandang Disabilitas Pasal 24. Hak atas informasi dalam penelitian ini sesuai dengan Undang- Undang Nomor 8 Tahun 2016 tentang Penyandang Disabilitas Pasal 24, dan poin yang diambil adalah poin $\mathrm{b}$ dan poin $\mathrm{c}$.

\footnotetext{
${ }^{9}$ Zulkarnain Ridlwan, "Protection of Contitutiion Rights Of Persons With Disabilities," Fiat Justisia 7, no. 2 (2013), https://media.neliti.com/media/publications/36884-ID-perlindungan-hak-hak-konstitusional-penyandangdisabilitas-rights-of-persons-wit.pdf.
} 


\section{b) Hak Kesehatan Reproduksi}

Peraturan seputar hak kesehatan reproduksi telah diatur dalam Peraturan Pemerintah Republik Indonesia Nomor 61 Tahun 2014. Peraturan pemerintah ini menjelaskan mengenai peraturan-peraturan seputar kesehatan reproduksi bagi perempuan dan anak secara keseluruhan pada Pasal 26. Pasal ini menjelaskan bahwa para perempuan penyandang disabilitas juga memiliki hak kehidupan seksual yang sama dengan masyarakat pada umumnya.

Provinsi Jawa Tengah juga telah memiliki peraturan daerah memiliki khusus untuk para penyandang disabilitas yaitu Peraturan Daerah Provinsi Jawa Tengah Nomor 11 Tahun 2014 tentang Pemenuhan Hak Penyandang Disabilitas, dimana dalam Pasal 23 juga mengatur tentang hak kesehatan reproduksi bagi para penyandang disabilitas.

Menurut BKKBN (2000), untuk mewujudkan pemenuhan hak-hak reproduksi, maka kebijakan teknis operasional yang dilakukan di Indonesia adalah sebagai berikut ${ }^{10}$ :

1) Promosi Hak-Hak Reproduksi

Dilaksanakan dengan menganalisis peraturan perundang-undangan dan kebijakan yang saat ini berlaku apakah sudah sesuai dan mendukung hak-hak reproduksi dengan tidak melupakan kondisi lokal sosial budaya masyarakat. Pelaksanaan upaya pemenuhan hak reproduksi memerlukan dukungan secara politik dan legislatif sehingga bisa tercipta undang-undang hak reproduksi yang mencakup aspek pelanggaran hak-hak reproduksi.

2) Advokasi Hak-Hak Reproduksi

Advokasi dimaksudkan agar mendapatkan dukungan dan komitmen dari para tokoh politik, tokoh agama, tokoh masyarakat, LSM/ LSOM, dan swasta. Dukungan dari pihak swasta dan LSM sangat dibutuhkan karena ruang gerak pemerintah yang lebih terbatas. Dukungan para tokoh sangat membantu memperlancar terciptanya pemenuhan hak-hak reproduksi. Peran LSM yang memperjuangkan hak-hak reproduksi sangat penting artinya untuk upaya terwujudnya pemenuhan hak-hak reproduksi.

3) KIE (Komunikasi Informasi Dan Edukasi) Hak-Hak Kesehatan Reproduksi KIE diharapkan masyarakat semakin mengerti hak-hak terkait kesehatan reproduksi sehingga dapat bersama-sama mewujudkan kesehatan keluarga.

4) Sistem Pelayanan Hak-Hak Reproduksi

Dari keempat poin pemenuhan hak kesehatan reproduksi dan dokumen International Conference On Population And Development (ICPD) Kairo 1994 poin 1 yaitu hak untuk mendapatkan informasi dan pendidikan kesehatan reproduksi serta poin ke-11 yaitu hak untuk bebas dari segala bentuk diskriminasi dan kesehatan reproduksi. Penelitian ini akan mengkaji bagaimana pemenuhan hak kesehatan reproduksi bagi perempuan penyandang disabilitas di Kota Semarang.

10 Iwan Kumalasari, Intan; Andhyantoro, Kesehatan Reproduksi Untuk Mahasiswa Kebidanan Dan Keperawatan (Pustaka Baru Press, 2013). 


\section{Pelaksanaan Peraturan Pemenuhan Hak Atas Informasi dan Hak Kesehatan Reproduksi Bagi Perempuan Penyandang Disabilitas di Kota Semarang \\ a) Hak Informasi}

Penyandang disabilitas di Kota Semarang umumnya tidak mengalami kendala dalam berkomunikasi serta memperoleh informasi dar lingkungan sekitar mereka dalam kehidupan sehari-hari. Hal tersebut dibuktikan dengan hasil wawancara yang dilakukan pada 6 narasumber perempuan penyandang disabilias. Seluruh narasumber mengatakan bahwa mereka telah mendapatkan pendidikan di sekolah luar biasa (SLB) sehingga dapat membantu mereka untuk berkomunikasi dan memperoleh informasi selain itu, mereka juga mengikuti Komunitas Sahabat Disabilitas (KSD) di Kota Semarang untuk tempat bertukar informasi.

Wawancara yang dilakukan dengan narasumber lain yaitu dari ketua dari Komunitas Sahabat Disabilitas (KSD) Kota Semarang. Beliau mengatakan bahwa para penyandang disabilitas di komunitas ini sebagian besar tidak mengalami kesulitan dalam masalah berkomunkasi dan saat kami tanya terkait pemberian informasi dari dinas terkait beliau mengatakan jika selama ini mereka secara aktif mencari informasi secara mandiri.

Untuk pelaksanaan hak atas informasi di SLB khusus tuna grahita yaitu SLB $\mathrm{Hj}$. Soemiyati, salah satu tenaga pengajar mengatakan bahwa pihak SLB sudah melakukan komunikasi yang efektif dalam memberikan informasi dan berkomunikasi untuk memberikan pelajaran kepada para muridnya bagi para penyandang disabilitas ini. Pelajaran yang diberikan di SLB ini seperti pelajaran yang ada di sekolah-sekolah pada umumnya seperti pelajaran matematika, Bahasa Indonesia, pelajaran olahraga, serta pelajaran tambahan yaitu keterampilan. Ibu D mengatakan bahwa untuk memberikan pelajaran sehari-hari, para tenaga pengajar sudah menggunakan media yang mudah dipahami oleh para penyandang disabilitas tunagrahita ini yaitu dengan media visual seperti gambar, karena media visual lebih mudah dipahami oleh para penyandang disabilitas tunagrahita.

Hak berekspresi, berkomunikasi, dan memperoleh informasi bagi para penyandang disabilitas sudah diperoleh dengan adanya bantuan teknologi, adanya komunitas yang menjadi wadah mereka untuk mengembangkan diri serta sekolah yang menjadi tempat mereka menimba ilmu. Hal ini sesuai dengan penelitian. ${ }^{11}$ mejelaskan bahwa SLB telah mengusahakan pemenuhan hak penyandang disabilitas berupa hak informasi, hak bekerja, dan lainnya yang dibutuhkan untuk persiapan merka menempuh jenjang pendidikan lebih lanjut ataupun untuk mereka bekerja setelah lulus.

Untuk pelaksanaan hak atas informasi bagi perempuan penyandang disabilitas di lembaga pemerintahan yaitu Dinas Kesehatan Kota Semarang, belum terlaksana dengan maksimal. Narasumber yang merupakan salah satu pegawai Dinkes Kota Semarang mengaku bahwa dinas tersebut bukan lembaga yang memiliki fungsi dan tugas yang berkaitan dengan disabilitas. Salah satu staf dari Puskesmas mengatakan bahwa selama

${ }^{11}$ Ulfah Fatmala Rizky, "Identifikasi Kebutuhan Siswa Penyandang Disabilitas Pasca Sekolah Menengah Atas," Indonesian Journal of Disabilities Atudies 1, no. 1 (2014): 52-59. 
ini hanya terdapat 1 orang penyandang disabilitas dengan tuna grahita yang memeriksakan dirinya ke Puskesmas dengan didampingi keluarganya dan kejadian itu sudah lama terjadi. Tidak adanya penyandang disabilitas yang memeriksakan kesehatan di Puskesmas disebabkan oleh kurangnya kompetensi petugas Puskesmas untuk berkomunikasi dengan penyandang tunagrahita menyebabkan petugas kesehatan tersebut bingung untuk memahami kebutuhan dari penyandang tunagrahita.

Akses informasi yang diberikan oleh Dinas Sosial bagi penyandang disabilitas di Kota Semarang diberikan hanya melalui media sosial seperti facebook, dan website Pemerintah Kota Semarang. Kolom lapor walikota yang ada di website Pemerintah Kota Semarang secara tidak langsung dapat membantu Dinas Sosial untuk menganggapi keluhan-keluhan yang disampaikan oleh para penyandang masalah kesejahteraan sosial untuk segera ditindak lanjuti

Dinas Pemberdayaan dan Perlindungan Anak (DP3A) telah melaksanakan program penggunaan sistem informasi/ teknologi untuk perlindungan anak dan pemberdayaan perempuan dalam bidang kesehatan mental dan psikososial. DP3A juga sudah menyelenggarakan bimbingan teknis penanganan korban kekerasan terhadap perempuan dan anak bagi tenaga kesehatan Kota Semarang sebagai bentuk pemenuhan hak atas informasi bagi penyandang disabilitas.

Perkumpulan Keluarga Berencana Indonesia (PKBI) adalah salah satu instansi yang sudah merancang program pemenuhan informasi kesehatan reproduksi bagi tunagrahita, meskipun masih dalam tahap sosialisasi dengan para orang tua dan guru SLB. Upaya yang dilakukan oleh Dinas Sosial harus didukung maksimal sesuai dengan Istifarroh et al. (2019) dan Putra (2019) yang menyatakan bahwa penyandang disabilitas perlu dilindungi untuk mendapatkan pekerjaan di perusahaan yang merupakan bagian dari hak hidup. ${ }^{12}$ Upaya pemenuhan dari hak bekerja ini merupakan bagian dari hak informasi sampai dengan pelaksanaan pekerjaannya di perusahaan tersebut. ${ }^{13}$

Dari hasil wawancara yang dilakukan pada beberapa narasumber serta data yang diperoleh di lapangan dapat disimpulkan bahwa implementasi hak informasi bagi penyandang disabilitas di Kota Semarang belum dilakukan secara optimal. Kurang optimalnya pemberian informasi kepada penyandang disabilitas dari pemerintah Kota Semarang ini disebabkan oleh tidak adanya komunikasi yang baik dan bersinergi antara dinas-dinas terkait yang bertanggung jawab. Dinas terkait diharapkan dapat bekerjasama satu sama lain untuk mengkaji lebih dalam permasalahan-permasalahan khusus bagi para penyandang kesejahteraan sosial seperti fasilitas umum, pelayanan kesehatan, akses informasi, dan lain sebagainya.

\section{b) Hak Kesehatan Reproduksi}

Wawancara yang dilakukan dengan anggota komunitas disabilitas yaitu KSD menunjukkan dari 6 orang anggota yang diwawancarai, hanya 1 anggota yang terpenuhi

${ }^{12}$ Widhi Cahyono Istifarroh; Nugroho, "Perlindungan Hak Disabilitas Mendapatkan Pekerjaan Di Perusahaan Swasta Dan Perusahaan Milik Negara,” Mimbar Keadilan Volume 12, no. Nomor 1 (2019): 21-34.

${ }^{13}$ Pamungkas Satya Putra, "Aksesibilitas Perlindungan Hukum Bagi Tenaga Kerja Penyandang Disabilitas Di Kabupaten Karawang,” Mimbar Hukum - Fakultas Hukum Universitas Gadjah Mada 31, no. 2 (2019): 205, https://doi.org/10.22146/jmh.44200. 
kebutuhan informasi atau pendidikan seputar kesehatan reproduksi. Hal tersebut menunjukkan bahwa pelaksanaan hak kesehatan belum berjalan secara maksimal. SKPD juga belum melaksanakan tugas dengan maksimal dalam upaya pemberian hak dan informasi terkait kesehatan reproduksi pada disabilitas. Berbagai peraturan yang dibuat oleh pemerintah sebagai upaya untuk memenuhi hak dari para penyandang disabilitas belum semuanya terlaksana.

Satu responden yang terpenuhi kebutuhan informasinya dan memperoleh pengetahuan yang baik seputar kesehatan resproduksi merupakan seorang tunanetra berusia 14 tahun dan sedang mengenyam pendidikan di sebuah SLB swasta. Responden mengatakan bahwa di sekolah tempat dia mengenyam pendidikan, dia memperoleh pelajaran tambahan tentang kesehatan reproduksi, yang berkisar seputar alat-alat reproduksi laki-laki dan perempuan, namun tidak begitu mendalam sedangkan lima responden penelitian lainnya mengatakan sama sekali belum pernah mendapatkan pelajaran tambahan seputar kesehatan reproduksi. Kelima responden ini mengatakan bahwa mereka hanya mendapatkan pelajaran terkait kesehatan dasar, seperti merawat diri dan kebersihan lingkungan .

Wawancara di SLB Hj. Soemiyati yaitu SLB khusus tuna grahita dengan 2 orang narasumber yaitu Bapak $S$ sebagai kepala sekolah yang berlatar belakang pendidikan sarjana pendidikan dan seorang tenaga pengajar bernama Ibu D seputar akses informasi kesehatan reproduksi. Kedua narasumber tersebut mengatakan bahwa hingga hari ini, SLB Hj. Soemiyati belum pernah mendapatkan akses informasi seputar kesehatan reproduksi dari pihak manapun. Ibu D menjelaskan bahwa murid di SLB ini tidak pernah memperoleh pendidikan terkait kesehatan reproduksi dan hanya diajarkan seputar kebersihan diri secara umum. Untuk akses informasi dalam rangka pemenuhan hak informasi bagi para murid SLB ini, Ibu D mengatakan bahwa para muridnya sudah bisa mengakses informasi sendiri seperti internet, karena hampir semuanya difasilitasi gadget (smartphone) dari orang tuanya.

Hasil wawancara Ibu D menunjukkan bahwa sebagian besar pernyandang disabilitas di SLB Hj. Soemiyati belum paham bagaimana cara mengelola informasi dengan benar contohnya adalah ketika Ibu D mendapati salah satu muridnya menyimpan video porno di smartphone-nya, murid tersebut bahkan mengetahui link yang bisa dia akses untuk mengunduh video tersebut. Ibu D juga menambahkan bahwa menurut beliau pendidikan tentang kesehatan reproduksi sendiri sangat penting untuk para anak berkebutuhan khusus ini untuk mencegah terjadinya kekerasan seksual.

Penyandang disabilitas kelompok tuna grahita ini merupakan ragam disabilitas yang memiliki keterbatasan dalam kemampuan berpikir dan tingkah laku sehingga peran orang tua dan orang terdekat sangat penting disini untuk memberikan bimbingan dan pengawasan terhadap setiap akses informasi yang semakin mudah diperoleh oleh anak.

Terkait bagaimana keseharian para orang tua murid dengan anaknya di rumah seputar pemeriksaan kesehatan, Ibu D juga tidak begitu mengetahui hal tersebut karena 
beliau hanya menanyakan seputar perkembangan dari masing-masing murid tersebut. Terkait dengan akses dari Puskesmas setempat seputar informasi kesehatan reproduksi, Ibu D mengatakan bahwa Puskesmas belum pernah memberikan sosialisasi seputar kesehatan reproduksi, akses dari Puskesmas sendiri hanya berupa pemberian vaksin.

Obyek penelitian ini di salah satu Puskesmas di Kota Semarang untuk menanyakan perihal pemenuhan hak atas informasi dan hak kesehatan reproduksi bagi perempuan penyandang disabiltas namun, salah satu staf mengatakan bahwa hingga saat ini, mereka hampir tidak menemui seorang pasien dari kalangan penyandang disabilitas.

Peraturan Daerah Jawa Tengah Nomor 11 tahun 2014 tentang Pemenuhan Hak Penyandang Disabilitas Pasal 23 telah mencanangkan kebijakan bahwa SKPD kabupaten maupun kota yang memiliki fungsi dan tugas di bidang kesehatan namun, dari hasil wawancara penelitian ini menjelaskan bahwa hampir tidak ada para penyandang disabilitas yang pernah mendapatkan informasi dan pendidikan seputar kesehatan reproduksi. Hal ini menunjukkan bahwa SKPD terkait di Kota Semarang belum melaksanakan kebijakan yang ada di peraturan daerah Jawa Tengah tersebut.

Wawancara yang dilakukan pada insitusi-institusi yang terkait dengan bidang kesehatan terutama kesehatan reproduksi dan penyandang disabilitas baik itu institusi pemerintah dan non-pemerintah. Institusi pemerintah yang dimaksud yaitu Dinas Kesehatan Kota Semarang, Dinas Sosial Kota Semarang, dan DP3A Kota Semarang sedangkan institusi non-pemerintah adalah PKBI Kota Semarang.

Terkait dengan pertanyaan program kerja khusus dari untuk penyandang disabilitas di Kota Semarang, Bapak H mengatakan, Dinas Kesehatan Kota Semarang tidak memiliki program khusus di bidang pelayanan kesehatan bagi penyandang disabilitas. Bapak H juga menambahkan bahwa saat ini, layanan unit khusus disabilitas sudah diterapkan di setiap Puskesmas. Salah satu bentuk pelayanan kesehatan ramah disabilitas yaitu terdapat jalan khusus selain tangga bagi masyarakat penyandang disabilitas agar mereka lebih mudah memperoleh akses kesehatan. Puskesmas juga telah dilengkapi adanya pegangan baik itu pada jalan naik maupun turun, dan hal ini pun sudah masuk dalam standar akreditasi pelayanan rumah sakit dan Puskesmas.

Fasilitas kesehatan di Puskesmas yang ramah penyandang disabilitas sayangnya tidak diimbangi dengan kemampuan tenaga kesehatan untuk berkomunikasi dengan penyandang disabilitas. Sarana pelayanan ramah penyandang disabilitas umumnya hanya dapat ditemukan di rumah sakit tertentu saja. Contoh kasus yang terjadi yaitu adanya terapis untuk tuna wicara, tuna rungu mereka punya kemampuan untuk memberikan akses atau memberlakukan komunikasi dengan teman disabilitas. Beberapa rumah sakit di Kota Semarang yang memiliki sarana kesehatan bagi penderita disabilitas yaitu Rumah Sakit Kariadi, Rumah Sakit Sultan Agung, Rumah Sakit Tugurejo sedangkan untuk Puskesmas belum ada sama sekali.

Dinas Kesehatan Kota Semarang telah berusaha memberikan pelayanan kesehatan yang berkualitas, dan berkeadilan bagi para penyandang disabilitas, dengan memberikan 
aksesibilitas fisik seperti jalan khusus untuk para penyandang disabilitas di beberapa pelayanan kesehatan Kota Semarang, meskipun hal itu belum dilakukan secara komprehensif. Peraturan daerah Provinsi Jawa Tengah No 11 Tahun 2014 Pasal 19 menjelaskan bahwa upaya pelayanan kesehatan yang harus diberikan pada para penyandang disabilitas yaitu meliputi promotif, preventif, dan kuratif. Terkait dengan pemenuhan hak atas informasi dan hak kesehatan reproduksi sendiri, Pasal 23 ayat (1) Peraturan Daerah Jawa Tengah Nomor 11 Tahun 2014 Pasal 23 ayat (1) terkait kesehatan reproduksi menunjukkan bahwa Dinas Kesehatan Kota Semarang merupakan sebuah SKPD yang memiliki tugas di bidang kesehatan dan seharusnya memberikan pendidikan seputar kesehatan reproduksi bagi para penyandang disabilitas. Narasumber dari Dinkes Kota Semarang menjelaskan bahwa pelayanan seputar kesehatan reproduksi masih mencakup pelayanan pada masyarakat umum, belum terdapat pelayanan khusus bagi penyandang disabilitas. Narasumber juga mengatakan bahwa semua hal yang terkait dengan penyandang disabilitas merupakan tugas dari Dinas Sosial.

Kesimpulan yang diperoleh dari hasil wawancara narasumber adalah diperlukan adanya komunikasi dan kerjasama antara Dinas Kesehatan dan Dinas Sosial Kota Semarang guna membuat program kerja seputar pemberian pendidikan kesehatan reproduksi bagi para penyandang disabilitas di Kota Semarang. Salah satu masalah yang dihadapi oleh Dinas Sosial adalah sulitnya untuk memperoleh informasi terkait para penyandang disabilitas karena sebagian keluarga dari penyandang disabilitas ini tidak pernah melapor perihal adanya anggota keluarga mereka yang merupakan penyandang disabilitas. Beberapa bahkan terkadang tidak memasukkan anggota keluarga yang merupakan penyandang disabilitas ke dalam kartu keluarga, tidak membuatkan mereka KTP, dan juga memasukkan anggota keluarga mereka ke dalam komunitas disabilitas. Berdasarkan permasalahan yang disampaikan di atas, dapat terlihat bahwa pengetahuan masyarakat seputar penyandang disabilitas masih relatif sangat rendah. Hal tersebut yang menyebabkan mereka selalu terkucilkan dari lingkungan, bahkan tidak diperhatikan oleh keluarga sendiri. Partisipasi dari masyarakat terutama dari keluarga para penyandang disabilitas sendiri sangat berperan penting karena dapat mempengaruhi perkembangan dari para penyandang disabilitas itu sendiri.

Penjelasan dari Pasal 80 dan 81 Peraturan Daerah Jawa Tengah Nomor 11 Tahun 2014 tentang Penyandang Disabilitas menunjukkan bahwa pemerintah daerah memberikan kesempatan bagi masyarakat luas untuk ikut berpartisipasi dalam pemenuhan hak penyandang disabilitas. Partisipasi masyarakat tersebut tidak harus dalam sebuah lembaga, komunitas, maupun badan hukum yang terkait, tapi dari keluarga sendiri dan masyarakat sekitarnya juga diharapkan turut mendukung pemenuhan penyandang disabilitas. Hal ini sejalan dengan Sholihah (2016) yang menjelaskan bahwa dengan berlakunya Undang-Undang No 8 Tahun 2016 tentang Penyandang Disabilitas, sinkronisasi dan pembenahan di segala bidang harus dilakukan termasuk data penyandang disabilitas untuk pemenuhan hak-hak mereka lebih luas. ${ }^{14}$

${ }^{14}$ Imas Sholihah, “Kebijakan Baru: Jaminan Pemenuhan Hak Bagi Penyandang Disabilitas,” Sosio Informa 2, no. 2 (2016): 166-84, https://doi.org/10.33007/inf.v2i2.256. 
Partisipasi yang dilakukan tersebut bisa berupa pemberian kesempatan dan perlakuan yang sama bagi para penyandang disabilitas, pengadaan aksesbilitas, pemberian bantuan, penyelenggaraan pendidikan, penyediaan pelayanan kesehatan, pemberian kesempatan kerja, pemberian saran dan pertimbangan kepada pemerintah daerah, pemberian pelayanan sosial, hingga kegiatan lain yang mendukung upaya pemenuhan penyandang disabilitas.

Salah satu narasumber dalam penelitian ini adalah Ibu Y yang merupakan salah satu pegawai Dinas Sosial di Kota Semarang yang bertugas di bagian rehabilitasi sosial penyandang disabilitas. Beliau mengatakan bahwa program dari Dinas Sosial terkait penyandang disabilitas sudah direncanakan sejak tahun 2016 kemudian baru terealisasikan pada awal tahun 2017. Saat awal dirintisnya program terkait penyandang disabilitas, Dinas Sosial mempersiapkannya secara mandiri tanpa adanya bantuan instansi lain. Dengan anggaran dana yang terbatas, Dinas Sosial melakukan beberapa kegiatan pelatihan bagi tuna netra, tuna rungu, melaksanakan peringatan hari autis dan hari disabilitas pada tahun 2017. Beberapa contoh kegiatan pelatihan yang diselenggarakan yaitu pelatihan pijat untuk tuna netra berupa pelatihan pijat tradisional dan herbal, sedangkan tuna rungu dibuat pelatihan membatik dan desain grafis. Pelatihan pijat untuk tuna netra berupa pelatihan pijat tradisional dan herbal, sedangkan tuna rungu dibuat pelatihan membatik dan desain grafis. Pelatihan-pelatihan yang diberikan tersebut dibuat sesuai kebutuhan dan keinginan dari para penyandang disabilitas tersebut.

Dinas Sosial dan Dinas Kesehatan Kota Semarang melakukan upaya untuk menjaring kerjasama terkait program bagi penyandang disabilitas adalah menjalin komunikasi dengan lembaga pendidikan, komunitas, dan pusat terapi namun, belum ada program khusus terkait yang direalisasikan saat ini. Dinas Sosial sampai saat ini belum memberikan akses khusus bagi para penyandang disabilitas dan masih sebatas upaya mensosialisasikan, dan memberikan himbauan kepada Bapak Walikota Semarang untuk menghimbau kepada seluruh jajaran pemerintah Kota Semarang untuk memberikan pelayanan yang ramah difabel. Beberapa contoh upaya pemerintah Kota Semarang yaitu dengan melengkapi kantor balai kota ram untuk kursi roda, parkir untuk penyandang disabilitas meskipun belum menyeluruh dan masih sebatas fisik atau aksesoris saja dan hanya terdapat satu kecamatan yang berinisiatif untuk membuat akses yang baik untuk para penyandang disabilitas yaitu Kecamatan Semarang Barat.

Ketika ditanyakan mengenai akses pelayanan kesehatan disabilitas, Ibu Y mengatakan tidak ada, begitu juga dengan pelayanan khusus seputar kesehatan reproduksi bagi penyandang disabilitas, Ibu Y mengatakan sampai saat ini belum ada pelayanan seperti itu, termasuk dalam pemberian sosialisasi seputar kesehatan reproduksi bagi para penyandang disabilitas. Terkait dengan pemenuhan pelayanan yang sudah diberikan bagi para penyandang disabilitas sendiri, Ibu Y mengatakan bahwa jika dilihat dari responnya, kebutuhan dari para penyandang disabilitas tersebut belum sepenuhnya terpenuhi. Dinas sosial sudah membuat himpunan masyarakat inklusi Kota Semarang itu sebagai wadah 
komunitas-komunitas difabel dari seluruh wilayah Kota Semarang dan dari situ juga diadakan diskusi bersama antar komunitas-komunitas tersebut.

Partisipasi dari sebagian masyarakat Kota Semarang terhadap pemenuhan hak penyandang disabilitas sudah cukup baik, hal tersebut terlihat dari warga yang berinisiatif untuk menciptakan lingkungan sekitar menjadi lingkungan yang ramah bagi para penyandang disabilitas. Dinas Sosial Kota Semarang juga telah melakukan pemenuhan aksesbilitas fisik seperti penyediaan ram kursi roda, parkir untuk penyandang disabilitas dan lain-lain. Begitupun dengan aksesbilitas non-fisik seperti pemberian informasi sudah dilakukan oleh Dinas Sosial Kota Semarang.

Upaya pemenuhan hak informasi dan hak kesehatan reproduksi bagi para penyandang disabilitas belum masuk ke dalam program kerja Dinas Sosial dan berdasarkan hasil wawancara dengan narasumber, permasalahan pendidikan kesehatan reproduksi bagi perempuan umumnya merupakan wewenang dari Dinas Kesehatan dan DP3A. Beberapa peraturan yang telah disusun oleh pemerintah memang dianggap sudah cukup untuk memenuhi hak dari para penyandang disabilitas namun, tidak semua peraturan tersebut dilaksanakan dan diimplementasikan.

\section{Faktor-Faktor Yang Mempengaruhi Pemenuhan Hak Atas Informasi Dan Hak} Kesehatan Reproduksi Bagi Perempuan Penyandang Disabilitas Di Kota Semarang

\section{a) Faktor pendukung}

Penelitian ini menyimpulkan bahwa faktor-faktor pendukung terlaksananya upaya pemenuhan hak atas informasi dan kesehatan reproduksi perempuan penyandang disabilitas di Kota Semarang yaitu faktor pemerintah, faktor advokasi, dan yang terakhir faktor dari para perempuan penyandang disabilitas itu sendiri.

\section{Pemerintah}

Sebelumnya telah dijabarkan bahwa pemenuhan hak-hak para penyandang disabilitas telah tertuang secara rinci dalam Undang-Undang No. 8 Tahun 2016. Implementasi dari UU No.8 Tahun 2016 di Kota Semarang tentang penegakan hak penyandang disabilitas dalam hal ini pemberian hak kesehatan reproduksi dapat dilihat dari upaya pemerintah untuk memberikan fasilitas kesehatan yang ramah bagi penyandang disabiltas. Contoh upaya yang dilakukan oleh pemerintah adalah memberikan jalur khusus bagi para penyandang disabilitas pada beberapa fasilitas kesehatan seperti Puskesmas. Hal tersebut diharapkan dapat menjadi faktor pendukung dalam upaya pemenuhan hak kesehatan reproduksi perempuan penyandang disabilitas di Kota Semarang.

Upaya pemerintah Kota Semarang yang telah dilakukan dalam penegakan hak atas informasi bagi para penyandang disabilitas adalah pemberian informasi bagi para penyandang disabilitas pada website pemerintahan Kota Semarang. Pemerintah Kota Semarang juga myediakan kolom pengaduan layanan publik yang dapat diakses oleh siapa saja termasuk penyandang disabilitas dan keluarga. 


\section{Advokasi}

Menurut BKKBN (2000), terdapat beberapa poin penting kriteria terpenuhinya hak kesehatan reproduksi di indonesia, salah satunya adalah advokasi hak-hak reproduksi, dimana advokasi yang dimaksudkan adalah agar mendapatkan dukungan komitmen dari para tokoh politik, tokoh agama, tokoh masyarakat, LSM/LSOM, dan swasta ${ }^{15}$.

Dalam penelitian ini menyimpulkan berdasarkan hasil wawancara dengan beberapa narasumber bahwa faktor pendukung utama dalam upaya pemenuhan hak atas informasi dan kesehatan reproduksi para penyandang disabilitas adalah adanya peraturan pemerintah terkait upaya pemenuhan hak penyandang disabilitas serta dukungan penuh dari LSM di Kota Semarang.

LSM ini secara aktif dan mandiri melakukan beberapa program terkait upaya pemenuhan hak atas informasi dan kesehatan reproduksi para perempuan penyandang disabilitas di Kota Semarang. PKBI Kota Semarang sebagai salah satu LSM yang berfokus pada kesehatan reproduksi sudah memiliki program terkait pemberian informasi dan pendidikan seputar kesehatan reproduksi bagi penyandang disabilitas tunagrahita. Meskipun program ini baru mulai berjalan dan baru diberikan pada penyandang disabilitas tunagrahita, PKBI Kota Semarang di waktu yang akan datang diharapkan dapat menjadi salah satu tonggak dalam tercapainya pemenuhan hak atas informasi dan hak kesehatan reproduksi di Kota Semarang.

\section{Penyandang Disabilitas}

Faktor dari penyandang disabilitas itu sendir serta keluarga sangat penting dalam upaya pemenuhan hak atas informasi dan kesehatan reproduksi. Penyandang Disabilitas diharapkan lebih aktif dalam upaya memperoleh informasi dan hak kesehatan reproduksi. Bentuk upaya aktif yang dapat dilakukan adalah mengikuti Pendidikan di SLB sehingga mereka dapat berkomunikasi dengan lingkungan sekitar tanpa hambatan. Selain itu, sebagian besar penyandang disabilitas di Kota Semarang juga aktif bergabung dalam suatu komunitas yang dapat menjadi wadah atau tempat bertukar informasi.

\section{b) Faktor Penghambat}

\section{1) Pemerintah}

Beberapa hambatan yang dihadapi terkait lambatnya program bagi penyandang disabilitas adalah terbatasnya anggaran dana. Hambatan lain yang terjadi adalah kurangnya komunikasi antara dinas terkait seperti Dinas Kesehatan, Dinas Sosial, dan Pemerintah Daerah terkait dengan pemenuhan hak atas informasi dan hak untuk pemenuhan kesehatan reproduksi perempuan penyandang disabilitas di Kota Semarang.

Pemerintah Kota Semarang masih kurang aktif dalam melakukan upaya pemenuhan hak-hak para penyandang disabilitas. Penyandang disabilitas terkesan mendapatkan perlakuan diskriminatif secara tidak langsung dikarenakan kurangnya sumber daya manusia dalam pemerintah yang dapat berkomunikasi dengan baik dengan para penyandang disabilitas. Hal tersebut yang menyebabkan kurang maksimalnya pelayanan

${ }^{15}$ Kumalasari, Intan; Andhyantoro, Kesehatan Reproduksi Untuk Mahasiswa Kebidanan Dan Keperawatan. 
publik bagi para penyandang disabilitas sehingga mereka tidak memperoleh hak-hak yang seharusnya.

Hal ini sesuai dengan yang diuraikan oleh Cahyono dan Probokusumo dalam jurnalnya bahwa terdapat perlakuan diskriminatif dalam memenuhi kebutuhan dasar seperti mengikuti hak pendidikan, layanan kesehatan, pekerjaan, akses mobilitas fisik dan sosial, rekreasi serta persamaan dalam hukum dan politik. Perlunya bagi dinas sosial untuk dapat konseling terhadap keluarga maupun masyarakat untuk pemenuhan hak-hak mereka ${ }^{16}$.

\section{2) Masyarakat}

Hasil wawancara dengan narasumber dari Dinas Sosial Kota Semarang, diketahui bahwa Dinas Sosial mengalami kesulitan dalam mencari informasi dan data seputar para penyandang disabilitas sebab terkadang ada keluarga dari para penyandang disabilitas yang tidak mengakui keberadaan salah satu anggota keluarganya yang merupakan penyandang disabilitas. Hal ini membuktikan bahwa partisipasi masyarakat untuk mendukung para penyandang disabilitas masih sangat kurang.

Bapak $\mathrm{H}$ yang merupakan narasumber dari Dinas Kesehatan juga mengatakan bahwa terkadang untuk kasus kekerasan seksual bagi para penyandang disabilitas sendiri, masih banyak masyarakat yang tidak melapor karena takut adanya ancaman, para aparat terkait juga terkadang kesulitan berkomunikasi dengan para penyandang disabilitas, sehingga informasi yang didapat tidak maksimal.

\section{3) Tenaga Kesehatan}

Tenaga kesehatan tidak memiliki kompetensi untuk berkomunikasi dengan para penyandang disabilitas. Ketika terjadi kasus kekerasan seksual, para tenaga kesehatan tidak mampu menggali informasi seputar kejadian yang dialami oleh penyandang disabilitas, karena kesulitan berkomunikasi dengan para penyandang disabilitas. Selain itu, keluarga atau orang terdekat yang bertindak sebagai pendamping dan penerjemah terkadang tidak memberikan informasi yang lebih rinci karena juga tidak paham dengan kondisi yang sebenarnya terjadi pada para penyandang disabilitas.

Dalam Konvensi Hak-Hak Penyandang Disabilitas Pasal 25 poin (d) menjelaskan bahwa para professional di bidang kesehatan diwajibkan oleh negara untuk menyediakan hak kesehatan baik perawatan atau pun kegiatan kesehatan lainnya secara merata kepada penyandang disabilitas. Hal tersebut belum sepenuhnya dilakukan oleh pelayanan kesehatan terkait, sebab belum adanya penekanan terkait kebijakan khusus kompetensi pelayanan pada para penyandang disabilitas dari undang-undang kesehatan.

\section{4) Penyandang Disabilitas}

Hasil wawancara seputar informasi kesehatan reproduksi, penelitian ini menangkap bahwa para penyandang disabilitas di Kota Semarang belum sepenuhnya mendapatkan informasi dan hak kesehatan reproduksi karena mereka sendiri tidak pernah diajarkan bahkan diberikan pengetahuan seputar kesehatan reproduksi baik di keluarga,

${ }^{16}$ Sunit Agus Tri Cahyono and Pantyo Nugroho Probokusumo, "Hak-Hak Disabel Yang Terabaikan Kajian Pemenuhan Kebutuhan Dasar Penyandang Disabilitas Keluarga Miskin,” Media Informasi Penelitian Kesejahteraan Sosial 40, no. 2 (2020): 93-108. 
masyarakat, maupun di sekolah tempat mereka menimba ilmu. Pendidikan seputar kesehatan reproduksi tentunya sangat penting diberikan pada para penyandang disabilitas, karena para penyandang disabilitas juga memiliki hak untuk mendapatkan informasi seputar kesehatan reproduksi.

Ketua KSD menuturkan bahwa salah satu hambatan dari kurang terpenuhinya hak atas informasi dan hak kesehatan reproduksi bagi perempuan penyandang disabilitas sendiri adalah karena banyaknya ragam disabilitas. Para penyandang disabilitas ini memiliki tingkat kemampuan berpikir serta berkomunikasi yang berbeda satu dengan lainnya, sehingga perlu semacam warming up atau pemanasan kira-kira sampai dimana kemampuan para penyandang disabilitas tersebut. Banyaknya ragam disabilitas membuat mereka kesulitan bagaimana penyampaian informasi tentang kesehatan reproduksi ini dapat tersampaikan dan diterima dengan baik oleh penyandang disabilitas.

\section{5) Kebijakan}

Belum adanya kebijakan khusus terkait kesehatan reproduksi bagi penyandang disabilitas. Undang-undang kesehatan serta peraturan pemerintah yang dibuat masih berupa pemenuhan hak kesehatan reproduksi secara umum. Selain itu, adanya Pasal 2 Undang-Undang Nomor 11 Tahun 2009 tentang Kesejahteraan Sosial ini membatasi kemandirian dari para penyandang disabilitas karena para penyandang disabilitas ini dimasukkan ke dalam prioritas masyarakat yang memiliki kehidupan yang tidak layak secara kemanusiaan dan memiliki kriteria masalah sosial. Hal ini tentu sama saja tidak memberikan kebebasan pada para penyandang disabilitas untuk mandiri, karena mereka dianggap tidak layak untuk melakukan hal umum seperti yang dilakukan pada masyarakat pada umumnya. Hal ini pun yang kemudian memuculkan stigma dan diskriminasi pada masyarakat. Widjaja dkk dalam penelitiannya menjelaskan bahwa perlunya pemerintah berkomitmen untuk mengawasi dan membenahi kebijakan terkait penyandang disabilitas untuk hak-haknya. Komitmen untuk pembenahan kebijakan ini memberikan perlindungan kepada penyandang disabilitas dalam pemenuhan hak mereka yang lebih luas ${ }^{17}$.

\section{E. PENUTUP}

Pelaksanaan pemenuhan hak atas informasi bagi perempuan penyandang disabilitas di Kota Semarang sudah terlaksana dengan baik sesuai dengan peraturan perundangundangan serta kebijakan dari daerah yang berlaku namun, pemenuhan hak kesehatan reproduksi bagi perempuan penyandang disabilitas di Kota Semarang belum terlaksana dengan baik disebabkan oleh belum adanya pelaksanaan dari instansi pemerintah terkait. Faktor pendukung dari pemenuhan hak atas informasi dan hak kesehatan reproduksi bagi perempuan penyandang disabilitas di Kota Semarang adalah adanya advokasi hak-hak reproduksi berupa dukungan komitmen dari LSM di Kota Semarang dengan membuat program seputar pemberian informasi dan pendidikan kesehatan reproduksi bagi para penyandang disabilitas tunagrahita di Kota Semarang. Faktor penghambat yaitu anggaran

${ }^{17}$ Alia Harumdani Widjaja, Winda Wijayanti, and Rizkisyabana Yulistyaputri, "Perlindungan Hak Penyandang Disabilitas Dalam Memperoleh Pekerjaan Dan Penghidupan Yang Layak Bagi Kemanusiaan," Jurnal Konstitusi 17, no. 1 (2020): 197, https://doi.org/10.31078/jk1719. 
dana yang kurang, tidak ada sosialisasi dari pemerintah tentang kesehatan reproduksi, kurangnya partisipasi masyarakat untuk mendukung pemenuhan hak bagi penyandang disabilitas, tenaga kesehatan tidak kompeten dalam berkomunikasi kepada mereka, tidak terlaksananya kebijakan yang telah dibuat, serta tidak ada ketentuan khusus yang mengatur tentang pemberian informasi dan pendidikan seputar kesehatan reproduksi. Pemerintah sebaiknya lebih memperhatikan lagi kondisi para penyandang disabilitas tidak hanya dari permasalahan yang umum seperti tindakan rehabilitatif, namun juga pada permasalahan yang khusus seperti banyaknya kasus kekerasan seksual yang terjadi pada para perempuan penyandang disabilitas. Pemerintah juga diharapkan dapat menyediakan sarana dan prasarana yang mendukung bagi penyandang disabilitas untuk memperoleh informasi dan pengetahuan yang cukup terkait kesehatan reproduksi. Koordinasi antara lembaga terkait juga sangat diperlukan dalam upaya pemenuhan hak atas informasi dan pemenuhan pengetahuan kesehatan reproduksi perempuan disabilitas di Kota Semarang.

\section{DAFTAR PUSTAKA}

A. Priamsari, RR. Putri. "Hukum Yang Berkeadilan Bagi Penyandang Disabilitas." $\begin{array}{llllll}\text { Masalah-Masalah Hukum } \quad 48, \quad \text { no. } & 2 & \text { (2019): } 215 .\end{array}$ https://doi.org/10.14710/mmh.48.2.2019.215-223.

Ali, H.Zinuddin. Metode Penelitian Hukum. Sinar Grafika, 2015.

ASK, Tim Penulis Sobat. "5 Masalah Seksualitas Yang Dialami Penyandang Disabilitas," 2017. http://www.sobatask.net.

Benuf, Kornelius, and Muhamad Azhar. "Metodologi Penelitian Hukum Sebagai Instrumen Mengurai Permasalahan Hukum Kontemporer." Metodologi Penelitian Hukum Sebagai Instrumen Mengurai Permasalahan Hukum Kontemporer 3, no. 2 (2019): 145-60.

Cahyono, Sunit Agus Tri, and Pantyo Nugroho Probokusumo. "Hak-Hak Disabel Yang Terabaikan Kajian Pemenuhan Kebutuhan Dasar Penyandang Disabilitas Keluarga Miskin.” Media Informasi Penelitian Kesejahteraan Sosial 40, no. 2 (2020): 93108.

Herjantam, Ignatius. "Perempuan Penyandang Disabilitas Rentan Alami. Ketidakadilan Berlapis," 2017. http://www.beritasatu.com.

Irawan, Ardi. "Peranan Pemerintah Daerah Istimewa Yogyakarta Dalam Perlindungan Hukum Terhadap Perempuan Penyandang Disabilitas Korban Kekerasan." Jurnal Ilmiah Hukum De'Jure Volume 2, no. Nomor 2 (2017): 2013-2218.

Istifarroh; Nugroho, Widhi Cahyono. "Perlindungan Hak Disabilitas Mendapatkan Pekerjaan Di Perusahaan Swasta Dan Perusahaan Milik Negara.” Mimbar Keadilan Volume 12, no. Nomor 1 (2019): 21-34.

Kumalasari, Intan; Andhyantoro, Iwan. Kesehatan Reproduksi Untuk Mahasiswa Kebidanan Dan Keperawatan. Pustaka Baru Press, 2013.

Pawestri, Aprilia. "Hak Penyandang Disabilitas Dalam Perspektif Ham Internasional Dan Ham Nasional." Era Hukum 15, no. 1 (2017): 164-82.

Putra, Pamungkas Satya. "Aksesibilitas Perlindungan Hukum Bagi Tenaga Kerja Penyandang Disabilitas Di Kabupaten Karawang." Mimbar Hukum - Fakultas 
Hukum Universitas Gadjah Mada 31, no. 2 (2019): 205. https://doi.org/10.22146/jmh.44200.

Ridlwan, Zulkarnain. "Protection of Contitutiion Rights Of Persons With Disabilities." Fiat Justisia 7, no. 2 (2013). https://media.neliti.com/media/publications/36884ID-perlindungan-hak-hak-konstitusional-penyandang-disabilitas-rights-ofpersons-wit.pdf.

Rizky, Ulfah Fatmala. "Identifikasi Kebutuhan Siswa Penyandang Disabilitas Pasca Sekolah Menengah Atas." Indonesian Journal of Disabilities Atudies 1, no. 1 (2014): 52-59.

Rofiah, S. "Harmonisasi Hukum Sebagai Upaya Meningkatkan Perlindungan Hukum Bagi Perempuan Penyandang Disabilitas Korban Kekerasan Seksual." Qawwam 11, no. September 2016 (2017): 133-50. https://journal.uinmataram.ac.id/index.php/qawwam/article/view/747.

Sholihah, Imas. "Kebijakan Baru: Jaminan Pemenuhan Hak Bagi Penyandang Disabilitas." Sosio Informa 2, no. 2 (2016): 166-84. https://doi.org/10.33007/inf.v2i2.256.

Widjaja, Alia Harumdani, Winda Wijayanti, and Rizkisyabana Yulistyaputri. "Perlindungan Hak Penyandang Disabilitas Dalam Memperoleh Pekerjaan Dan Penghidupan Yang Layak Bagi Kemanusiaan.” Jurnal Konstitusi 17, no. 1 (2020): 197. https://doi.org/10.31078/jk1719. 